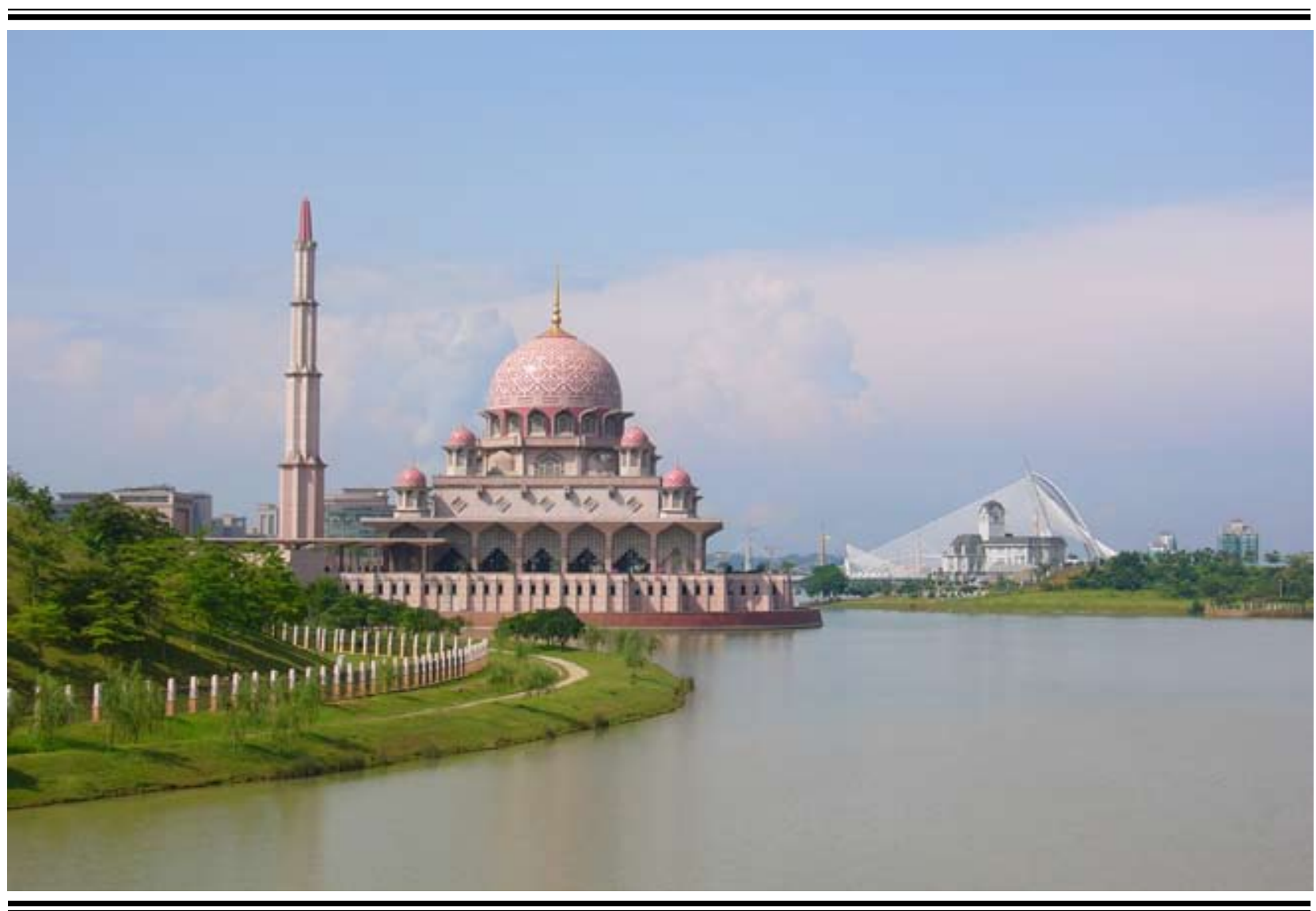

MASJID PUTRA (PUTRA MOSQUE)

\title{
PUTRAJAYA: A CAPITAL FOR THE FUTURE
}

\section{BY STAFFORD D. OLIVER \\ PHOTOGRAPHY BY SARAH MOSER}

This essay considers capital beyond its usual economic context and explores its meaning in two different but related senses of the word: the seat of government and an entity that is recognized as valuable. I refer to a transformation of capital by discussing the city of Putrajaya in Malaysia. The city was built as a part of the government's plans for the future, specifically the Vision 2020 national development initiative, so as to implement the ultimate objective of a 'fully developed'Malaysia. It is also the location of the Prime Minister and federal bureaucracy. Despite all of the plans, visions, and construction, the future remains unknown and Putrajaya as a capital is not yet finished.

\section{'IT IS THE FUTURE THAT HAUNTS US WITH ITS ORAC- ULAR DOOM’ (BAXSTROM 2008: 84).}

'HOPEFULLY THE MALAYSIAN WHO IS BORN TODAY AND IN THE YEARS TO COME WILL BE THE LAST GENERATION OF OUR CITIZENS WHO WILL BE LIVING IN A COUNTRY THAT IS CALLED "DEVELOPING”. THE ULTIMATE OBJECTIVE THAT WE SHOULD AIM FOR IS A MALAYSIA THAT IS A FULLY DEVELPED COUNTRY BY THE YEAR 2020',

-TUN DR MAHATHIR BIN MOHAMAD, MALAYSIA:THEWAY FORWARD, 28 FEBRUARY 1991(1997 [1991]b: 403)
Dutrajaya is a recently built planned-city in 1 Malaysia, south of Kuala Lumpur (KL) in a region called the Multimedia Super Corridor (MSC). I contend that the city refers to the transformation of capital in a double sense of the word. Successive Malaysian governments have had plans for such a city since the 1970s (King 2008: 112-113), but the building of Putrajaya began in the mid-1990s by the administration of Tun Dr Mahathir bin Mohamad during his 
30-year national development initiative called Wawasan 2020 or Vision 2020. Using the city to discuss capital in its common connotation as it relates to capitalism would be very easy, since Vision 2020 sets out to achieve certain economic targets and make Malaysia a powerful actor in the world economy (Mahathir 1997 [1991]b: 403; see Greider 1997 [2004]). However, capital is not only economic. Putrajaya is explored as a capital of a different kind in two related contexts.

Capital should not only be considered as wealth, profit, and investments. More than that, capital is also something that is recognized as valuable. Addressing capital as a valuable based on recognition shows how it can have various meanings and levels of significance in different contexts, for recognition is based on familiarity. Additionally, capital may also refer to a city or town that is the seat of government. KL remains Malaysia's official capital and home of the Sultan and Parliament. Meanwhile, Putrajaya is the location of the Office of the Prime Minister, the most powerful politician, in the Perdana Putra building, along with most of the federal bureaucratic agencies which bear the authority to act on the government's behalf (King 2008: 153). These two definitions of capital are used to show that capital is not so much a fixed entity but is more involved in processes of becoming. In other words, capital is still being formed and is not yet finished. Capital probably will always be transforming. The word probably is used in order to highlight the uncertainty of what capital means in a given context and how it can and might change. This leads to a third concern: the future.

The future is a difficult subject to cover as I am not an oracle. Nevertheless, the future is emphasized in works about Malaysia, including families and relatedness (Carsten 1997: 257), urban life (Baxstrom 2012; Baxstrom 2011: 62-63), and of course politics (Robertson 1984; Mahathir 1997 [1991]b: 403; Ibrahim 1996). A point needs to be made, though, in order to address the future. Jane Guyer (2007: 409-410) distinguished between the 'near future' and the 'distant future' and noted that, as opposed to the 'near future', the 'distant future' is not about maintaining a continuity with the present. The interplay between these two proximities of the future and their distance to the present is note- worthy. The near future is 'a process of implicating oneself in the ongoing life of the social and material world' (Guyer 2007: 409). The distant future of a plan like Vision 2020, set to take 30 years to implement, relies more on 'emergent horizons of imagination' (Guyer 2007: 413). The distant future is not necessarily connected to the present and thus involves uncertainty. As much as there is hope, the future can also be risky. Potential outcomes can be dangerous and frightening as it is possible to imagine many possibilities, from triumph to doom, which cannot be completely known in the present. Even though the future is uncertain, its presence can still be felt.

The two quotes from Mahathir and Richard Baxstrom which began this essay illustrate concepts about the future plus the recognized value of capital. Together these statements may seem contradictory, since I mostly discuss an optimistic period in Malaysia from 1991 through 1997. These years, at the beginning of the boom of the 1990s and just before the Asian Financial Crisis, brought large-scale economic growth and optimism (Greider 1997 [2004]: 163). Mahathir made his hopeful statement during the February 1991 'The Way Forward' speech in which he announced a vision for Malaysia's future (Mahathir 1997 [1991]b: 403). Before exploring the vision, it's insightful to address the ominous, scary, pessimistic, but accurate words from a moving chapter by Baxstrom (2008). His concept of a haunting future can finely describe the Malaysian government's perceptions of the future during the Mahathir era. I'm not suggesting that the future is a ghost, but I will show that Mahathir and his UMNO (United Malays National Organization) party colleagues addressed the future as an ambiguous, unknown and physical presence.

Hope was very much about making the future the now. Yet, the future has and continues to remain unknown. Consider the 1996 book The Asian Renaissance by Anwar Ibrahim, written when he was the Deputy Prime Minister of Malaysia under Mahathir. 'The future is embedded in time present. Yet, its shape and character is a matter of conjecture' (Ibrahim 1996: 127). He admitted that the future is strange despite its looming presence and closeness to the present. The future is that which has not yet 
happened, in spite of all of the speculations, dreams, guesses, hypotheses, plans, and feelings of imminence. Thus, uncertainty is a feature of the future. As A.F. Robertson (1984:1) wrote, 'insofar as we are dealing with a future which is always uncertain, planning is a hazardous activity'. Like Baxstrom (2008) claimed, the uncertainty and probability of what will and may happen can be very disturbing and unsettling. Plans emerge as attempts to grapple with the unknown (un)certainty of the not yet.

\section{BUILDING FOR THE FUTURE}

Malaysia in the 1990 s, similar to many other countries, was determined to make the ultimate objective of a 'fully developed' future a reality. Through library-based research, I have analysed publications, policies and sentiments from the era. The most prominent person during this time was Mahathir. Malaysia's longest serving Prime Minister from 1981-2003, Mahathir dominated political life during his years in office (see Hilley 2001). At the inaugural address before the first meeting of the Malaysia Business Council, an organisation of which he was the first chairman, Mahathir delivered 'The Way Forward' in which he outlined a vision for Malaysia's future (Mahathir 1997 [1991]a; Mahathir 1997 [1991] b). The speech identified nine goals/challenges which he thought that Malaysia should implement and/or overcome in order to become a 'fully developed' country by the year 2020 (Mahathir 1997 [1991]b). Vision 2020, comprehensive and ambitious, seeks to create by the year 2020 Malaysia as 'a nation that is fully developed along all the dimensions - economically, politically, socially, spiritually, psychologically and culturally' (Mahathir 1997 [1991]b: 404). The government proposed an absolute, detailed and concrete version of the future. As a national development plan, economics is a part of $\mathrm{Vi}$ sion 2020. 'The ninth is the challenge of establishing a prosperous society, with an economy that is fully competitive, dynamic, robust and resilient' (Mahathir 1997 [1991]b: 405). The realistic goal sought to make the country's 2020 GDP 8 times larger than it was in 1990, which would require growth at seven per cent annually (Mahathir 1997 [1991]b: 408). These and other aspects of Vision 2020's capital can be addressed in subsequent research, though. My focus here is the question: 'How is it possible to plan without a concrete sense of the future' (Baxstrom 2012: 136)? With such comprehensive visions and swift efforts, the government tried to remove the uncertainty of the future and attempted to literally construct it. From the start, it seems that the goals were supposed to not eventually lead to but become the future.

Ahmad Sarji, the editor of Malaysia's Vision 2020: Understanding the Concept, Implications \& Challenges, a lengthy book with chapters from academics, politicians and business leaders which outlines Vision 2020, explained that, 'a vision is a mental image of a future state of being which can be clearly perceived to be better or more attractive than the present state' (Ahmad 1997: xiii). Such mental images were quickly conveyed and gained a physical presence through large-scale projects. There are several examples including the Petronas Towers in Kuala Lumpur City Centre, built as the world's tallest building, and the Kuala Lumpur International Airport (see Bunnell 2004). Literally between those two, emerged a capital building initiative that served as an example of what the future will be like and a method to make Mahathir's imagination a physical reality, objectifying the ultimate objective. The vision became tangible, and it seems that this was the intention from the beginning. Planning in Malaysia has such a long history (Robertson 1984) that Vision 2020 and Putrajaya reflect and augment, which is possible to explore, but I'm still left with the question of is it really possible to build the future?

The grandest project of Vision 2020 is the Multimedia Super Corridor. About the size of Singapore with an area of $50 \mathrm{~km} \times 15 \mathrm{~km}$, the MSC was a government initiative led by Mahathir to create a space for technological innovation and creativity (Bunnell 2004: 1-10). Large government investments in the telecommunications infrastructure of the MSC's cities of Putrajaya and Cyberjaya make the area the most digitally wired place in the country (Lepawsky 2005). Located within the MSC, Putrajaya is the federal administrative centre of Malaysia (King 2008: xxii), which is no coincidence. Plans for a powerful and modern Ma- 

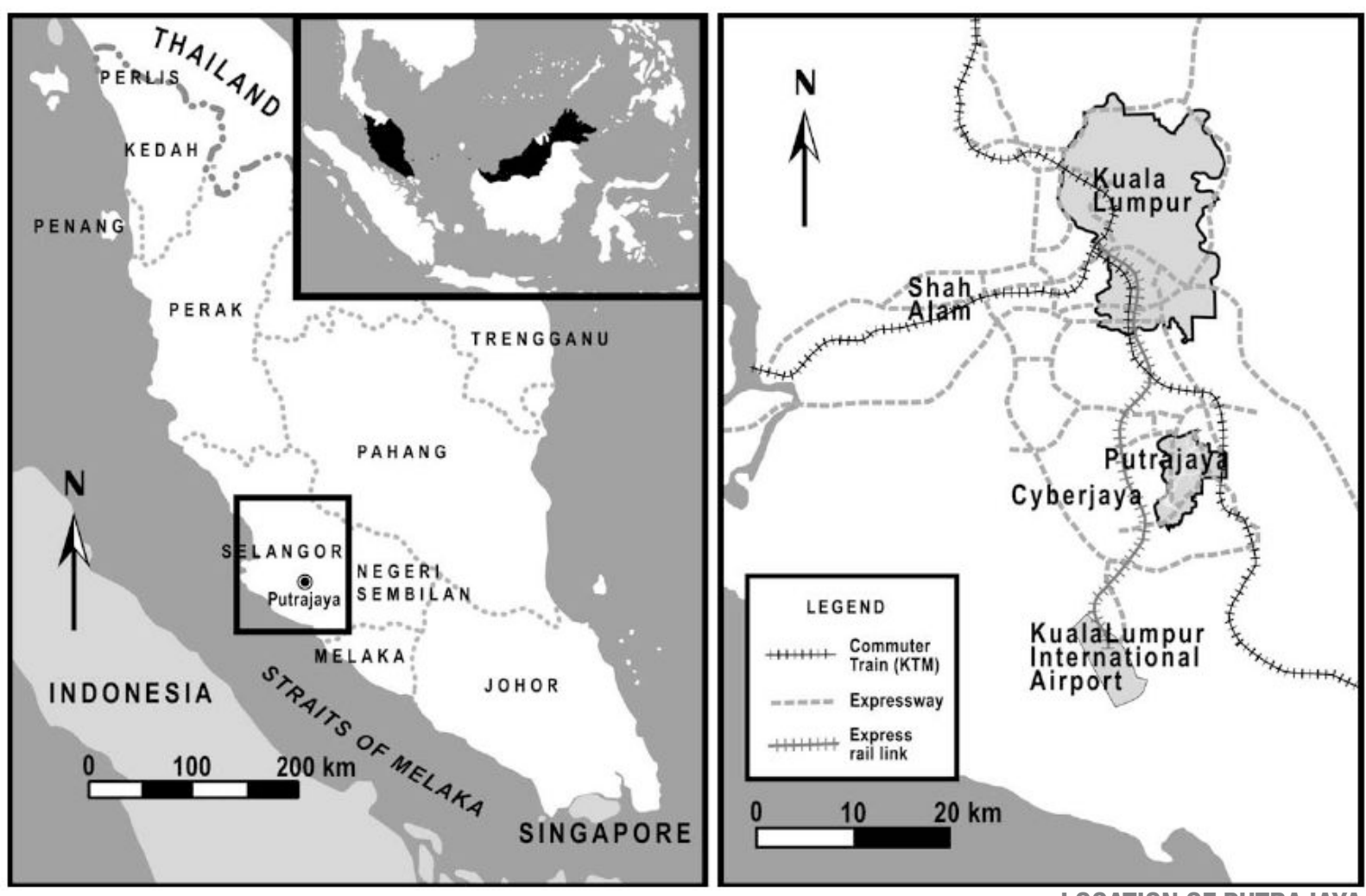

LOCATION OF PUTRAJAYA

laysia necessitated a particular urban dominion.

Now, I should make it clear that these concepts are not particularly unique to Malaysia under Mahathir or UMNO. There have been and continue to be similar development and capital projects throughout the world. Numerous governments, organisations and institutions attempt to take 'an authoritative grip' on their future via planning (Robertson 1984: 1). The perspective on capital that I use with Putrajaya is not new, as there are many places which deploy capital in similar ways. In her description of Putrajaya, Sarah Moser (2010) discusses several. These include contemporary cities such as Chandigarh and Hyderabad in India and Brasília in Brazil, plus the historical headquarters of Shah Abbas in Isfahan (also spelt as Esfahan) in Safavid Persia and Akbar's court at Fatehpur Sikri in Mughal South Asia. Washington, D.C., built in the early years of the United States of America, could also be considered. Additionally, it would also be easy to compare Putrajaya to other cities in Malaysia, namely metropolitan KL (King 2008) and the wider Johor Bahru region (Moser 2011; Rizzo and Glasson 2012).

These other cities are mentioned briefly due to space limits and because the Southeast Asian concept of the exemplary seems more apt to consider capital. Some instances of exemplary centres include hearths (Carsten 1997), houses (Chua 2007: 274), persons' bodies (Tsintjilonis 1999), and principal cities (Geertz 1980; Tambiah 1976). The exemplary centre is described as a 'microcosm and embodiment of cosmological and political order' (Chua, Cook, Long and Wilson 2012: 5), an actualisation of the divine. The centre may draw people in and encompass them, compelling a movement on its surroundings into its domains in order to extend its reach and concentrate power (Carsten 1998: 225; Chua 2007: 274). According to Clifford Geertz (1980: 4) the term Negara describes pre-European polities in Bali, Indonesia in addition to the capital cities in and through which leaders ruled. In contemporary Malaysia Negara refers to the nation, for which Ross King (2008: 99) determined that the capital city must represent the country.

Geertz's Negara concept explored an archetype of exemplary and central rule. 'The court shapes the world around it into at least a rough approximation of its own excellence' (Geertz 1980: 13). The ruler's capital was a model for which all subjects were governed and by which they should live. Moreover, this idea of rule gained an everyday presence through rituals and symbolic objects (Geertz 1980: 13). The 


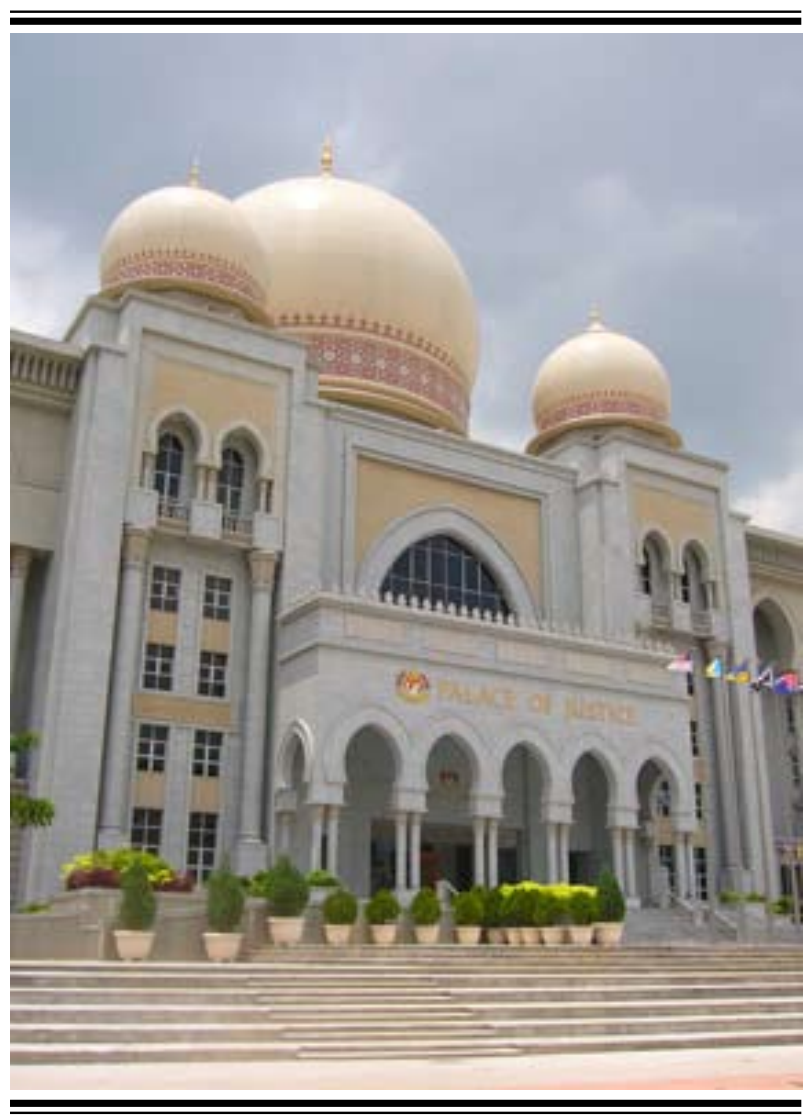

ISTANA KEHAKIMAN (PALACE OF JUSTICE)

specific organisation of the political capital was the primary concern of Stanley Tambiah's (1976) study of Buddhist and Hindu principalities in Thailand. The mandala concept portrayed the polity and the capital as an inner core with orbiting peripheral areas, proposing 'a galactic picture of a central planet surrounded by differentiated satellites, which are more or less "autonomous" entities held in orbit and within the sphere of influence of the center' (Tambiah 1976: 113). Ideally, the ruler's capital and area of direct control was in the middle, surrounded by 'a circle of provinces ruled by princes or governors appointed by the king, and these again were surrounded by more or less independent “tributary" polities' (Tambiah 1976: 112). The mandala ideal was difficult to physically implement, but nonetheless one which leaders sought to impose. The organisation of the capital resembled the cosmos and this connection makes the centre divine (Tambiah 1976).

I wish to emphasize the centre and the way in which people participate in it. Benedict Anderson (1990 [1972]: 41-43) noted that the increased size of a centre corresponded to the greater influence of the ruler. Increasing the centre required the movement of neighbouring areas and people, and as such the centre pulled. Yet, the persons on the peripheral areas and/or in adjacent polities sought to avoid being inscribed (Carsten 1998: 218). Movement was a key feature since the centre expanded, but also because satellites engaged in disputes, switched alliances, or persons moved away (Anderson 1990 [1972]: 41-43). The centre is composed of people, and the actions of people constitute the centre. Moreover, being recognized as an exemplary and sovereign centre was the goal of earlier polities. It is at this point that the two definitions of capital that I use combine. Recognition allowed the leader to stay in power and to inscribe more people to his realm. 'Performative validity' (Tambiah 1976: 125) required an audience (Geertz 1980). However, earlier polities were on-going projects, as they were never really finished, expanding and contracting, as the amount of people increased or diminished.

Regional scholarship explains how ideals are manifested and to some extent informs aspects of Vision 2020. As Janet Carsten wrote, 'in Southeast Asia the traditional state was defined by its centre' (Carsten 1998: 217). This is still true. Development schemes draw from existing repertoires ( $\mathrm{Li}$ 2007: 6). A 'fully developed' Malaysia requires a 'fully developed' capital. Vision 2020 imagines Malaysia's 'fully developed' future as a tangible place. Ramasamy, Chakrabarty and Cheah (2004) even described the MSC as Malaysia's leap into the future. Though I find problems with their line of enquiry in that they essentially equate the MSC, Malaysia's future, with the USA's Silicon Valley, the present, their work portrays the 'if you build it, they will come' hope of the era.

Mahathir, the architect of Vision 2020 (Ahmad 1997: xv), personally supervised the planning of Putrajaya (King 2008: 153). Though the city is named after Malaysia's first Prime Minister Tunku Abdul Rahman Putra (Moser 2010: 286), the city is associated with Mahathir (King 2008: 125). King inferred that the PM attempted to construct a centre in which the Prime Minister and bureaucracy would disconnect and consume the power of the Sultan and legislature along with all of Malaysia (King 2008: 153 -159). Additionally, the relocation of the Office 
of the Prime Minister and federal bureaucracy to Putrajaya fixed Malaysian political life to revolve around the Prime Minister. Perdana $\mathrm{Pu}-$ tra, the building which houses the Office of the Prime Minister, is the focus of the grand $4.2 \mathrm{~km}$ axis of Putrajaya (King 2008: 153; Moser 2010: $289)$. Thus the PM is the focus of the city. Further, axes are usually only reserved for capital cities (King 2008: 153). Perdana Putra, marked by towering domes, suggests a link between Islam, the religion associated with Malays and the Malay ethnicity. Religion was definitely considered a feature of the renaissance (Ibrahim 1996: 19). The government's quest for modernity is connected with certain Islamic practices and forms inspired by polities from the Middle East and South Asia (Moser 2011; Moser 2010; King 2008: 182). The domes on top of the political centre suggest that 'the underlying agen$\mathrm{da}$ is the advancement of Malaysia as a MalayMuslim polity, a new kind of high-modernist Muslim nation' (King 2008: xxiv). Thus, urban landscape is the medium in which a specific future was envisioned and in which it will arrive.

The decision to build Putrajaya was formally approved in June 1993 (King 2008: 131) and building began in 1995 (Moser 2010: 285). I contend that the construction of projects informs why Mahathir insisted that Vision 2020 had become a reality in his 1997 speech 'Vision 2020: The Way Forward' (Mahathir 1997: 449). The vision for the 'fully developed' future assumes an urban form in Putrajaya. A vision can become a reality, but can the future be now? In that same speech, Mahathir (1997: 458) asserted that Malaysians needed to act to capture and seize the future. As imminent as it may have been perceived, the future was out of reach and impossible to completely know or grasp. In a way, Mahathir admitted such. 'We can congratulate ourselves for the progress that we have made. But we cannot lie back' (Mahathir 1997: 457). In other words, Malaysia will still be developing.

Vision 2020 has and continues to attempt to make the future become the present. Putrajaya expressed a vision of and means to achieve that future. 'Political elites typically require a national capital to represent the nation. If the Malays would equate bangsa Melayu (the Malay "race") with negara (the nation), then the city likewise must stand as the emblem' (King 2008: 99). Mahathir intended to achieve a Malay-centred, ultra-modern realm by constructing a laudatory and spectacular city. Under his rule, 'development was thus reoriented to the interrelated production of high-tech spaces and citizens' (Bunnell 2004: 58). According to Timothy Bunnell, the former PM considered urban living 'as a potential incubator of modern Malayness' (Bunnell 2004: 44). He declared that 'those who are backward must be helped. No one must be left behind' (Mahathir 1997: 453). And herein lays the conundrum of Putrajaya as capital in both senses, a recognized valuable and a seat of government.

A 'wired' and connected space like Putrajaya furthers 'opportunities and advantages to those "tuned in" to the new order' (King 2008: 144). But the order intended to circumscribe people under the government's authority. Mahathir would be at the centre. But how does a leader get citizens to participate in and compose a 'fully developed' capital? What the government may deem as valuable may not be recognized as such by all citizens, a topic that deserves more research. Putrajaya was the government's attempt to transform for the future, however capital is still not yet. As concrete as Putrajaya may seem in that it is a constructed city, the 'fully developed' future has not been seized nor has it arrived and it may not ever. Though seeming to be close, the future's uncertain presence flows as unknown. Consider that the city physically existed by 2005 (King 2008: 158 ), but as of 2012 the population goals have not been reached (Putrajaya Holdings 2012). Only 72,000 out of the planned resident population of 350,000 actually lives in the city $(\mathrm{Pu}-$ trajaya Holdings website). A 'fully developed' Malaysia and its capital still 'is in the process of coming into being' (Ibrahim 1996: 129). Many things can happen but there is uncertainty of what will occur. Transformations continue. 삭

All images courtesy of Sarah Moser. Used with permission. 
Ahmad S. (1997) 'Understanding the Concept, Implications and Challenges of Malaysia's Vision 2020'. Pp. xii-xxi in Ahmad S. (ed.), Malaysia's Vision 2020: Understanding the Concept, Implications \& Challenges. Petaling Jaya: Pelanduk Publications.

Anderson, B. (1990 [1972]) 'The Idea of Power in Java'. Pp. 17-78 in B. Anderson (ed.), Language and Power: Exploring Political Cultures in Indonesia. Ithaca, USA: Cornell University Press.

Baxstrom, R. (2008) 'One Dead, One Missing: or "My Favorite Moments from a Dead Century". Pp. 81-94 in R. Baxstrom and T. Meyers (eds.), anthropologies. Baltimore, USA: Creative Capitalism.

Baxstrom, R. (2011) 'Even Governmentality Begins as an Image: Institutional Planning in Kuala Lumpur'. Focaal-Journal of Global and Historical Anthropology 61: $61-72$.

Baxstrom, R. (2012) 'Living on the Horizon of the Everlasting Present: Power, Planning and the Emergence of Baroque Forms of Life in Urban Malaysia'. Pp. 135-150 in L. Chua, J. Cook, N. Long, and L. Wilson (eds.), Southeast Asian Perspectives on Power. London: Routledge.

Bunnell, T. (2004) Malaysia, Modernity and the Multimedia Super Corridor: A Critical Geography of Intelligent Landscapes. London: RoutledgeCurzon.

Carsten, J. (1997) The Heat of the Hearth: The Process of Kinship in a Malay Fishing Community. Oxford: Clarendon Press.

Carsten, J. (1998) 'Borders, Boundaries, Tradition and State on the Malaysian Periphery'. Pp. 215-236 in T.M. Wilson and H. Donnan (eds.), Border Identities: Nation and State at International Frontiers. Cambridge: Cambridge University Press.

Chua, L. (2007) 'Fixity and Flux: Bidayuh (Dis)engagements with the Malaysian Ethnic System'. Ethnos: Journal of Anthropology 72 (2): 262-288.

Chua, L., Cook, J., Long, N., and Wilson, L. (2012) 'Introduction: Power and Orientation in Southeast Asia'. Pp. 1-15 in L. Chua, J. Cook, N. Long, and L. Wilson (eds.), Southeast Asian Perspectives on Power. London: Routledge.

Geertz, C. (1980) Negara: The Theatre State in Nineteenth-Century Bali. Princeton: Princeton University Press.
Guyer, J. (2007) 'Prophecy and the Near Future: Thoughts on Macroeconomic, Evangelical and Punctuated Time'. American Ethnologist 34 (3): 409-421.

Greider, W. (1997 [2004]) 'Wawasan 2020'. Pp. 160167 in F.J. Lechner and J. Boli (eds.), The Globalization Reader. Malden, Massachusetts, USA: Blackwell Publishing:.

Hilley, J. (2001) Malaysia: Mahathirism, Hegemony, and the New Opposition. London: Zed Books.

Ibrahim, A. (1996) The Asian Renaissance. Singapore: Times Books International.

King, R. (2008) Kuala Lumpur and Putrajaya: Negotiating Urban Space in Malaysia. Singapore: National University of Singapore Press.

Lepawsky, J. (2005) 'Stories of Space and Subjectivity in Planning the Multimedia Super Corridor'. Geoforum 36 (6): 705-719.

Li, T.M. (2007) The Will to Improve: Governmentality, Development, and the Practice of Politics. Durham, USA: Duke University Press.

Mahathir M. (1997) 'Vision 2020: The Way Forward'. Pp. 449-460 in Ahmad S. (ed.), Malaysia's Vision 2020: Understanding the Concept, Implications \& Challenges. Petaling Jaya: Pelanduk Publications.

Mahathir M. (1997 [1991]a) 'Inauguration Speech of the Malaysian Business Council'. Pp. 397-402 in Ahmad S. (ed.), Malaysia's Vision 2020: Understanding the Concept, Implications \& Challenges. Petaling Jaya: Pelanduk Publications.

Mahathir M. (1997 [1991]b) 'Malaysia: The Way Forward'. Pp. 403-420 in Ahmad S. (ed.), Malaysia's Vision 2020: Understanding the Concept, Implications \& Challenges. Petaling Jaya: Pelanduk Publications.

Moser, S. (2010) 'Putrajaya: Malaysia's New Federal Administrative Capital'. Cities: The International Journal of Urban Policy and Planning 27 (4): 285-297.

Moser, S. (2011). 'Constructing Cultural Heritage'. International Institute for Asian Studies Newsletter 57: 3031.

Putrajaya Holdings (2012) 'Putrajaya Facts'. Putrajaya Holdings Sdn Bd. [online] Available at http://www.pjh. com.my/corporate/putrajaya-facts/ 
Ramasamy, B., Chakrabarty, A., and Cheah, M. (2004)

'Malaysia's Leap into the Future: An Evaluation of the Multimedia Super Corridor'. Technovation 24 (11): 871 883.

Robertson, A.F. (1984) People and the State: An Anthropology of Planned Development. Cambridge: Cambridge University Press.

Rizzo, A. and Glasson, J. (2012) 'Iskandar Malaysia'. Cities: The International Journal of Urban Policy and Planning 29 (6): 417-427.

Tambiah, S. (1976) World Conqueror and World Renouncer: A Study of Buddhism and Polity in Thailand Against a Historical Background. Cambridge: Cambridge University Press.

Tsintjilonis, D. (1999) 'Being in Place and Being a Place: Sumanga' in Buntaó'. Bijdragen tot de Taal-, Land- en Volkenkunde 155 (4): 617-643.

\section{ACKNOWLEDGEMENTS}

I would like to thank Dimitri Tsintjilonis, Richard Baxstrom, Sarah Moser, the editors and the anonymous peer reviewer for their suggestions and insights. Their support is appreciated. 